\title{
UNIVERSITY OF WAIKATO
}

\author{
Hamilton
}

New Zealand

\section{How Do Workers' Remittances Respond to Lending Rates?}

Gazi M. Hassan and Mark J. Holmes

\section{Department of Economics}

\section{Working Paper in Economics 02/17}

February 2017

Corresponding Author

Gazi M. Hassan

Economics Department

University of Waikato

Private Bag 3105

Hamilton, 3240

NEW ZEALAND

Email: gmhassan@waikato.ac.nz

Phone: +64 (0)7 858-5164

Fax: +64 (0)7 838-4331

\section{Mark J. Holmes}

Economics Department

University of Waikato

Private Bag 3105

Hamilton, 3240

NEW ZEALAND

Email: holmesmj@waikato.ac.nz 


\begin{abstract}
We develop a simple model of altruistic transfer and debt-repayment showing that for plausible parameter values, the long-run effect of a change in real lending rates on remittance sending may be negative. Using data for a sample of eighty countries over a 1995-2014 study period, estimation by panel ARDL confirms a negative long-run role for real lending rates. We also find that remittance sending is more sensitive to real rates in the case of the high remittance-receiving countries, while less sensitive in the case of low remittance-receiving countries. An analysis of the dynamics of adjustment suggests that the short-run impact of interest rate changes on remittances is very limited.
\end{abstract}

\author{
Key Words \\ remittances \\ real interest rates \\ panel ARDL
}

\title{
JEL Classification
}

F0, F4, O1 


\section{INTRODUCTION}

Remittances sent out by migrants across the globe account for a sizeable component of global international flows. The magnitude of workers' remittances is more than three times the value of Official Development Assistance (ODA) worldwide, and second only to foreign direct investment (FDI) flows in developing countries. Workers' remittances to developing countries were estimated at US\$47 billion in 1980 (constant 2011 dollars), but officially recoded remittances, according to latest World Bank estimates, to developing countries were equivalent to US\$404 billion in $2013^{1}$. For developing and emerging economies, the importance of remittances is often substantial because these receipts often supply necessary international currency to finance import bills and also account for a substantial portion of the balance of payments current account.

Remittances provide a number of specific benefits to recipients, including the reduction of poverty, alleviation of credit constraints, and improvements in the educational and health outcomes of the recipient households (Adams and Page 2005, Cox-Edwards and Ureta 2003, Frank and Hummer 2002, Gupta et al. 2009, Hanson and Woodruff 2003, Hildebrant and Mckenzie 2005, Page and Plaza 2006 and Quartey and Blankson 2004). Remittances are instrumental in generating savings and the accumulation of productive assets by removing investment constraints and deepening the financial sector within the recipient economy (Ahamada and Coulibaly 2011, Bettin and Zazzaro 2011, Mundaca 2009, Arun and Ulku 2011 and Chiodi et al. 2012). The inflow of remittances can thus lead to accelerated investments in physical and human capital, remove households' credit constraints, and contribute towards long-run growth (Adams 2005, Borja 2014, Jouini 2015, Giuliano and Ruiz-Arranz 2009, Rao and Hassan 2011, Catrinescu et al. 2009, Feeny et al. 2014 and Siddique et al. 2012).

While remittances are compensatory flows, generating countercyclical behaviour enabling recipients to smooth their consumption (Chami et al. 2008 and 2009, Chami et al. 2005, Combes and Ebeke 2011, Kurosaki 2006, Mishra 2005 and Sayan, 2006) and reduce income volatility (Chami et al. 2008 and 2009, Yang and Choi 2007), the inflow of remittances does pose several development challenges in terms of controversial effects on economic growth (Chami et al. 2003, World Bank 2006 and IMF 2005), and the capacity of remittances to lead to an appreciation of the real exchange rate, thereby causing a Dutch disease effect (Amuedo-Dorantes and Pozo 2004, Acosta et al. 2007, Chami et al. 2008, Hassan and Holmes 2013 and Montiel 1999).

The macroeconomic role of workers' remittances is further underscored by their responsiveness to important policy variables. Moreover, theoretical and empirical models of migration suggest that the flows of remittances should be affected by key macroeconomic

\footnotetext{
${ }^{1}$ See http://go.worldbank.org/RR8SDPEHO0
} 
indicators such as interest rates and exchange rates (see, for example, Jackman 2013, Cooray and Mallick 2013 and Chami et al. 2005 and 2008). For instance, policies targeted at real exchange rate deprecation may serve the purpose both to enhance the receipts of remittances, and to improve the current account balance. Similarly, policies such as de-regulation of the financial sector or adoption of a floating exchange rate regime in order to attain a structural shift of resources towards the tradable goods sector are quite likely to affect international flow of remittances.

While a number of previous studies have assessed the impact of interest rates and exchange rate policies on remittances, the purpose of this paper is to offer a new interpretation on the responsiveness of remittances to real domestic lending rates. In doing so, we investigate whether debt-migration, that is, international migration where the costs of migration are covered by taking on a market loan, can influence remittances behaviour of the migrant once abroad. We differ from the existing new economics of labour migration (NELM) approach which views migrant remittances as repaying a family loan or extended family loan that has arisen from some form of contractual agreement between the household and the migrant to undertake the cost of migration and/or to finance potential migrant's education (Poirine 1997). Under this scenario, the exchange resulting in loan repayments occurs predominantly on account of the liquidity constraints faced by the migrant who undertakes the familial loan tied to non-market implicit interest rates. Indeed, the household finances a potential migrant's education if the family's implicit lending rate is higher than the market interest rate (Poirine 1997). However one of the major shortcomings of the loan repayment hypothesis is that it cannot be tested directly since the data on remittances between migrants and households other than their immediate family, that is, extended family, are generally not available from existing surveys (Ilahi and Jafarey 1999).

In this paper, we develop a framework to directly test whether debt repayment constitutes a significant component of the total remittances flows wherein the debt incurred to undertake migration is viewed as a form of market activity. The argument is based on the observation that international migration costs are quite substantial and above the financial possibilities of the migrants' family, requiring financing from all different sources available in the economy. Therefore, there is increasing evidence of debt-migration among migrants in Asia, Latin America as well as in other parts of the world where migrants pay their recruitment and travel expenses up front by borrowing at the market interest rate from money-lenders and other formal and non-formal institutions in addition to borrowing from the family (Osella and Osella 2000, Nair 1999, Rahman 2000 and 2015, Buckley 2011, Stoll 2010 and Loschmann and Seigel 2014). Since the lending rate represents the short to long term cost of financing in the economy, the debt-migration hypothesis - wherein the costs of migration are covered by taking on a market loan - can be directly tested by analysing the relationship between remittances inflow and domestic real lending rate. 
According to the theoretical literature on the migrants' motivation to remit, there exist plausible exchange motivations based on self-interest as well as altruistic motivations for sending remittances (Lucas and Stark 1985 and Stark 1991). However, despite a large number of empirical studies on the determinants of remittances flow, it is hard to distinguish which theories of remittances determination, that is, exchange or altruism, are identified because a positive or negative coefficient on a particular explanatory variable may be consistent with multiple theories. Some researchers find evidence that remittances respond to favourable investment opportunities in the home country. These studies have used interest rate of home country or interest rate differential of the home and host country in the empirical models (Faini 1994, Jackman 2013, Cooray and Mallick 2013, El-Sakka and McNabb 1999, Aydas et al. 2005, Allyene et al. 2008, Chami et al. 2005 and 2008) as a test for the exchange or self-interest theory of remittances. In particular, a positive coefficient on the interest rate or interest rate differential is regarded as an evidence of opportunistic remittances whereas an insignificant or negative coefficient would tend to invalidate support for remittances responding to favourable investment climate in the home country.

Our paper re-interprets and offers a fresh insight to the interest rate elasticity of remittances as a form of debt- repayment responsiveness rather being opportunistic or selfinterest/investment motives. The implication of this re-interpretation is that domestic lending rate alone may determine parts of remittances flows as opposed to interest differentials as underscored in many studies. As a result, home country policies towards macroeconomic management or financial liberalisation as well as structural adjustments may have greater role towards remittances determination than what is traditionally understood. Furthermore, remittances flows are often observed to be less volatile compared to most other forms of resources inflows (see Ratha 2003) which have been attributed to the altruistic component of remittances because of its less vigorous reaction to home economic conditions (Ratha 2003 and World Bank 2001). Related to this, we would like to emphasize that a statistically significant co-movement of remittances with domestic lending rates would also imply the stability of remittances, because remittances flows which are attached to debt repayment will also tend to be steady irrespective of home conditions.

The purpose of this paper therefore is to assess the impact of domestic real lending rates and exchange rate policies on remittances. We are particularly concerned with the possibility of how remittances respond to changes in the domestic real lending rate. We develop and estimate a simple model of altruistic transfer and debt-repayment and show that for plausible parameter values the long-run effect of a change in real lending rate on remittances may be negative. The paper is organised as follows. In section II we present a stylised model of remittances and debt-repayment. We argue that the domestic real lending rates play a crucial role in affecting steady state value of remittances. Based on the model, we derive an expression for remittances which is tested using panel time-series econometrics in Section III. The econometrics results are analysed and discussed in Section IV. Some brief policy considerations conclude the paper in Section V. 


\section{REMITTANCES AND DEBT-REPAYMENT: THE MODEL}

To assess the relevance of the hypothesis, our theoretical model is based on a utility maximisation framework following Faini (1994) where the instantaneous utility of the migrant is described by a Constant-Elasticity-of-Substitution (CES) function. We extend the Fiani (1994) framework by introducing into the constraints the repayment of debt incurred due to migration loan.

While the importance of interest rates have been documented in previous remittances models, a conspicuous omission from previous literature relates to the explicit modelling of the real lending rates on migrant family's consumption to gauge the effect of its changes on remittances. Simple intuition would suggest that the real lending rate and exchange rate should affect the behaviour of remittances whether seen from the context of altruistic or exchange-related models. Suppose that the migrant's income is given in terms of host country's good and also that recipient (migrant's family) consumption falls exclusively in terms of the home (host) country good. In an altruistic model, for a given level of debt, a decrease in the real domestic lending rate (a proxy measure for the cost of migration loan) will affect remittances through two pivotal channels.

Firstly, for a given level of consumption by the migrant of the host country good, it will enable greater consumption of the home good by the migrant's family for a particular level of debt. This is equivalent to a negative income effect on the consumption of home good of a decrease in lending rate in home country.

Secondly, there will be larger demand for the home country good through the substitution effect. If remittances are thus expressed in terms of the home country good, its responsiveness to the changes in domestic lending rate is unambiguously negative. That is, for a given level of debt, a decrease in real lending rates unequivocally raises remittances measured in terms of consumption of home good and vice versa. However, if remittances are rather expressed in terms of host country good, the substitution effect should be associated with larger remittances, but the income effect would work in the opposite direction. This is equivalent to the possibility that real remittances (in terms of the host country good) declines in the wake of a fall in lending rates in home country. Thus, it may argued that the impact of domestic lending rate on the behaviour of real remittances leaves open two possibilities. The realised impact could be either positive or negative depending on whether the income effect dominates the substitution effect or not and also whether remittances are viewed in terms of home or host country good.

To better assess the relevance of these considerations, we rely on the following simple extension of the Faini (1994) framework. Suppose that the migrant's utility is a function of both their own consumption and family consumption. Also assume that the instantaneous utility can be described by a CES function, that is: 


$$
U\left(C_{m}, C_{f}\right)=\left[(1-\beta) C_{m}^{-\delta}+\beta C_{f}^{-\delta}\right]^{-1 / \delta}
$$

The representative migrant maximises (1) subject to the following constraints:

$$
\begin{aligned}
& C_{f}=Y_{f}+\lambda R-r D=Y_{f}+R_{f}-r D \\
& C_{m}=Y_{m}-R
\end{aligned}
$$

where $C, R$ and $Y$ indicate consumption, remittances (in terms of the host country good) and income respectively, the subscripts $m$ and $f$ refer to the migrant and his family respectively, $\lambda$ denotes the real exchange rate (defined so that an increase in the index correspond to a real depreciation), $D$ is the value of migration loan and $r$ is the real market lending rate existing in the migrant's home country. Also $R_{f}=\lambda R$ represents remittances in terms of the home country good. We make explicit in Equation (2) our extension of the Faini (1994) framework by allowing for the consumption by the family to be equal to home income plus remittances net of the debt-payment (,that is, real lending rate times the amount of debt) which is paid at the outset. The term $r D$ in Equation (2) represents debt repayment where it is assumed that the representative migrant's debt-repayment is fixed for a given lending rate.

Equation (3) represents the consumption of the migrant which is equal to the difference between foreign income and remittances sent out. After substituting the constraints in Equation (2) and Equation (3) into Equation (1), taking derivatives with respect to $R$ then solving for the first-order condition for the optimal value of remittances, we find that:

$$
R=\frac{Y_{m}-\alpha\left(Y_{f}-r D\right)}{1+\alpha \lambda}
$$

where

$$
\alpha=\left\{\frac{\lambda \beta}{1-\beta}\right\}^{-1 / 1+\delta}=\left\{\frac{\lambda \beta}{1-\beta}\right\}^{-\sigma}
$$

with $\sigma$ denoting the elasticity of substitution between $C_{f}$ and $C_{m}$.

Some features of this model is worth noting. The expression of remittances in Equation (4) is very similar to that found in Faini (1994). However, the numerator includes an additional term $\alpha r D$ which signifies how remittances also depend on the real lending rate since $D$ is assumed fixed. While it is clear that remittances respond to the real lending rate, it is ambiguous in which direction $R$ moves in response to changes in $r$. If we consider the case where $\sigma=0$, then: 


$$
R=\frac{Y_{m}-Y_{f}+r D}{1+\lambda}
$$

and so a decrease in $r$ will lead to lower remittances because the substitution effects are weak and are dominated by (negative) income effects. However, for larger values of $\sigma$ (for instance $\sigma=1$ ), a decrease in $r$ may correspond to higher remittances flows and the magnitude of this responsiveness will depend on the level of debt, real exchange rate and the migrant's degree of altruism ${ }^{2}$.

\section{DATA AND METHODOLOGY}

Equations (4) and (6) postulate that the impact on $R$ resulting from changes in $r$ is ambiguous being dependent on $\sigma$. In assessing the relationship between $R$ and all the key driversincluding $Y_{m}, Y_{f}, \lambda$ and $r$, we employ a balanced panel of annual data for 80 countries covering the study period $1995-2014^{3}$. The sample of countries is listed in an appendix. Each of these countries is either a major remittances-sending country (for example, the United States) or a major remittances recipient (for example, India), while some countries possess both of these aspects (for example, Indonesia). In order to choose our sample of countries which are the main the migrant destination and source countries, we consulted the Migration and Remittances Factbook 2011 by the World Bank which lists the 30 top remittances sending countries and 30 top recipient countries. All remittances data are expressed in constant prices measured in US dollars.

Data on remittances are derived from balance of payments statistics provided by each country to the IMF. According to the Balance of Payments Manual 5 (BPM5), remittances data until 2005 comprised three categories: (1) workers' remittances, which are current transfers by migrant workers, where migrants are defined as individuals with resident status who come to work for at least a year; (2) compensation of employees that includes income earned by non-resident workers and (3) migrants' transfers, which are a capital account transfer reflecting the movement of assets by a migrant from one country to another when he or she migrates. The World Bank's World Development Indicators data combine workers' remittances and compensation of employees together to form the remittance measure reported therein, and this has been the definition of remittances used in a number of studies in the literature (for example, Catrinescu et al. 2009 and Rao and Hassan 2011). However, in practice it had been proven difficult by the respected country central bank authorities to

\footnotetext{
${ }^{2}$ If remittances are considered as host country good then the responsiveness is conditional on the level of debt $D$, the altruistic parameter $\beta$ and on real exchange rate $\lambda$. If, however, remittances are considered as home country good, the marginal effect of lending rate is only conditional on $D$ and $\beta$.

${ }^{3}$ All data are downloaded from World Development Indicators (http://databank. worldbank.org/data/home.aspx).
} 
separate transfers made by migrant workers from their employment income from a number of other transfers. Therefore, the Balance of Payments Manual 6 (BPM6) of the IMF replaced the category of workers' remittances with personal transfers which consist of 'all current transfers in cash or in kind made or received by resident households to or from non-resident households' (IMF 2009, p.20). Net remittances data which are used in our paper are extracted from the World Development Indicators (2016). This data are based on personal remittances (,that is,, personal remittances received net of personal remittances paid) being the sum of these personal transfers and compensation of employees. Hence, the current measurement of remittances data addresses many of the previous issues and concerns highlighted by LunaMartínez (2005), Singer (2010) and others.

In terms of the explanatory variables, the real lending rate is computed as this year's nominal rate adjusted for next year's actual inflation. Family income is measured by the real GDP of the home country. Migrant income is measured by the aggregation of real GDP values across fourteen remittance sending countries. All real GDP data are expressed in constant US dollars. Finally, the real exchange rate is measured as the real effective exchange rate as the relative price of tradable goods to non-tradable goods produced in the domestic economy following the methodology of Hassan and Holmes (2013).

Following the work of Pesaran et al. $(1999,2001)$ and others, we initially employ an estimation approach whereby a dynamic heterogeneous panel regression is incorporated into an error correction model using an autoregressive distributed lag $\operatorname{ARDL}(p, q)$ technique. For changes in $R$, we may write

$$
\Delta\left(R_{i t}\right)=\sum_{j=1}^{p-1} \vartheta_{j}^{i}\left(\Delta R_{i, t-j}\right)+\sum_{j=1}^{q-1} \vartheta_{j}^{i}\left(\Delta X_{i, t-j}\right)+\varphi^{i}\left[R_{i, t-1}-\left\{\tau_{0}^{i}+\tau_{1}^{i} X_{i, t-1}\right\}\right]+\epsilon_{i t}
$$

where $X$ is the set independent variables namely $Y_{m}, Y_{f}, \lambda$ and $r$. The $\tau$ coefficients represent the long-run coefficients based on the long-run equilibrium equation

$$
R_{i, t}=\tau_{0}^{i}+\tau_{1}^{i} Y_{m, i}+t, \tau_{2}^{i} Y_{f, i, t}+\tau_{3}^{i} \lambda_{i, t}+\tau_{4}^{i} r_{i, t}+e_{i, t}
$$

where $e$ is a long-run disturbance term and $\varphi^{\frac{i}{i}}$ is the coefficient of speed of adjustment towards long-run equilibrium. The term in the square brackets in Equation (7) contains the long-run remittances regression with all variables expressed in levels form. Pesaran and Shin (1999) argue that a panel ARDL such as this can be employed even with the variables being of different order of integration, ,that is, irrespective of whether the variables under study are $I(0)$ or $I(1)$. Both the short- and long-run effects can be estimated simultaneously from a data set with large cross-section and time dimensions. We estimate Equation (7) by maximum likelihood using dynamic fixed effects (DFE). The DFE estimator imposes restrictions on the 
slope coefficient and error variances to be equal across all countries in the long run. The DFE model further restricts the speed of adjustment coefficient and the short-run coefficient to be equal too. Baltagi et al. (2000) point out that this model is subject to a simultaneous equation bias due to the endogeneity between the error term and the lagged dependent variable in case of small sample size.

We consider the possibility of non-linear effects of real lending rates on remittances and so we apply tests for such effects using the threshold regression methods for nondynamic panels with the individual-specific fixed effects proposed by Hansen (1999).

$$
\begin{gathered}
R_{i, t}=\tau_{0}^{i}+\tau_{1}^{i} Y_{m, i, t}+\tau_{2}^{i} Y_{f, i, t}+\tau_{3}^{i} \lambda_{i, t}+\tau_{41}^{i} r_{i, t} I\left(q_{i, t-1} \leq \gamma\right)+\ldots \\
\ldots+\tau_{42}^{i} r_{i, t} I\left(q_{i, t-1}>\gamma\right)+e_{i, t}
\end{gathered}
$$

where I(.) is the indicator function, $q_{i, t-1}$ is the threshold variable and $\gamma$ is the threshold value. There are two regimes in this model. When $q_{i, t-1} \leq \gamma$, the effect of the real lending rate on remittances is $\tau_{41}^{i}$. When $q_{i, t-1}>\gamma$, the effect of the real lending rate on remittances is $\tau_{42}^{i}$. Hansen (1999) finds that for any given $\gamma$, the slope coefficients can be estimated by ordinary least squares estimation after fixed-effects transformations. The optimal threshold value for $\gamma$ is selected by sorting the distinct values of the observations on the threshold variable $q_{i, t-1}$ and eliminating the smallest and largest $5 \%$ of the observations of threshold variable; the optimal threshold value is the one that has the smallest sum of squared errors. Since under the null hypothesis the threshold is not identified, classical tests have nonstandard distributions. Hansen (1999) suggests a bootstrap to simulate the asymptotic distribution of the likelihood ratio test.

\section{RESULTS}

Table 1 reports the pooled mean group estimates of the long-run equation for the full sample of 80 countries. In terms of significant coefficients, we find $Y_{m}$ exerts a significant positive effect on remittances while $\lambda$ and the real lending rate have negative and significant coefficients. In terms of the linkage between real lending rates and remittances, the first row of the table based on the full sample of eight countries reports that a $1 \%$ fall in real rates leads to a $4.4 \%$ increase in remittances in the long-run. This finding is consistent with the model as set out in Equation (4) whereby $\sigma>0$ such that such decreases in $r$ lead to increased $R$ on account of strong substitution effects dominating negative income effects. It is also important to look more closely at potential nonlinearities in the linkage between real interest rates and remittances. In this respect, we consider whether the response of migrants to changes in real interest rates differs according to whether $r$ is viewed as relatively high or low. 
For the purpose of our analysis, we label high (low) interest rate countries are those countries for which the average real interest rate is greater (less) than the full sample average of $9.985 \%$ over the full study period. If we only consider the high interest countries only, then we still find respective positive and negative roles for $Y_{m}$ and $r$ in the long-run. There is a contrasting story in the case of the low interest countries where $Y_{f}$ and $\lambda$ are significant in the long-run. With no significant role for $r$, this leads us to find that remittances flows in the high interest rate countries are more sensitive to movements in the real interest rate. In terms of our model, migrants become more sensitive to real rates because higher rates as substitution effects increasingly dominate income effects resulting from changes in the real interest rate. If we further consider an additional distinction based on high- versus lowremittance countries for which remittances are on average greater or less than $1 \%$ of GDP over the study period, then $r$ exerts a significant influence in the long-run in both subsamples of countries. However, the high-remittance countries appear to be the relatively more sensitive to $r$ movements.

Table 1. Long-Run Relationships

\begin{tabular}{lcccc}
\hline & $\boldsymbol{Y}_{f}$ & $\boldsymbol{Y}_{m}$ & $\boldsymbol{\lambda}$ & $\boldsymbol{r}$ \\
\hline $\begin{array}{l}\text { All countries } \\
(\mathrm{N}=80)\end{array}$ & 1.135 & $2.488^{* *}$ & $-1.099^{*}$ & $-0.044^{* * *}$ \\
& $(0.834)$ & $(1.046)$ & $(0.589)$ & $(0.011)$ \\
$\begin{array}{l}\text { High interest } \\
\text { countries (N=63) }\end{array}$ & 1.000 & $3.042^{* *}$ & -0.975 & $-0.044^{* * * *}$ \\
& $(1.064)$ & $(1.324)$ & $(0.673)$ & $(0.012)$ \\
$\begin{array}{l}\text { Low interest } \\
\text { countries (N=17) }\end{array}$ & $2.240^{* *}$ & -0.281 & $-3.075^{* *}$ & -0.037 \\
$\begin{array}{l}\text { High remittances } \\
\text { countries }(\mathrm{N}=57)\end{array}$ & $(1.082)$ & $(1.456)$ & $(1.320)$ & $(0.030)$ \\
& 0.774 & $3.530^{* *}$ & $-1.436^{* *}$ & $-0.049 * * *$ \\
$\begin{array}{l}\text { Low remittances } \\
\text { countries }(\mathrm{N}=23)\end{array}$ & $(1.240)$ & $(1.526)$ & $(0.797)$ & $(0.015)$ \\
\hline
\end{tabular}

Notes

Estimation is by pooled mean group dynamic fixed effects. Figures in parentheses are standard errors, $*, * *$ and *** denote significance at the 1, 5 and 10\% levels respectively. High (low) remittances countries are those countries for which remittances are on average greater (less) than 1\% of GDP over the study period. High (low) interest rate countries are those countries for which the average real interest rate is greater (less) than the full sample average of $9.985 \%$ over the study period.

In terms of the short-run dynamics, Table 2 reports that the coefficient on the lagged error correction term $\varphi_{t-1}^{i}$ is both negative and significant throughout with values that range from -0.26 to -0.12 . Whereas the half-life of a shock to long-run equilibrium is approximated at 4.6 years for the full sample of 80 countries, the approximated half-life ranges from 2.3 (low remittance countries) to 5.4 years (high interest rate countries). The speed of adjustment towards long-run equilibrium is fastest for the high interest countries. The short-run results 
also suggest that $\Delta Y_{m}$ is a key general driver of short-run adjustment with limited roles played by home income and $\Delta \lambda$. In particular, $\Delta r$ only appears to exert a significant short-run influence on remittances in the case of the low remittances countries.

Table 2. Error Correction Models

\begin{tabular}{|c|c|c|c|c|c|c|}
\hline$\Delta \boldsymbol{R}_{t}$ & Constant & $\varphi_{t-1}^{i}$ & $\Delta Y_{f}$ & $\Delta Y_{m}$ & $\Delta \lambda$ & $\Delta r$ \\
\hline $\begin{array}{l}\text { All countries } \\
(\mathrm{N}=80)\end{array}$ & $\begin{array}{l}12.052^{* * * *} \\
(2.706)\end{array}$ & $\begin{array}{l}-0.140^{* * * *} \\
(0.015)\end{array}$ & $\begin{array}{c}0.082 \\
(0.359)\end{array}$ & $\begin{array}{l}3.108^{* * *} \\
(0.849)\end{array}$ & $\begin{array}{l}-0.144 \\
(0.148)\end{array}$ & $\begin{array}{c}0.001 \\
(0.001)\end{array}$ \\
\hline $\begin{array}{l}\text { High interest } \\
\text { countries } \\
(\mathrm{N}=29))\end{array}$ & $\begin{array}{l}13.561 * * * \\
(3.200)\end{array}$ & $\begin{array}{l}-0.135^{* * * *} \\
(0.018)\end{array}$ & $\begin{array}{l}-0.047 \\
(0.402)\end{array}$ & $\begin{array}{l}2.844 * * * \\
(0.990)\end{array}$ & $\begin{array}{l}-0.038 \\
(0.160)\end{array}$ & $\begin{array}{c}0.001 \\
(0.001)\end{array}$ \\
\hline $\begin{array}{l}\text { Low interest } \\
\text { countries } \\
(\mathrm{N}=51)\end{array}$ & $\begin{array}{r}4.4835 \\
(5.032)\end{array}$ & $\begin{array}{l}-0.178 * * * \\
(0.034)\end{array}$ & $\begin{array}{c}1.251 \\
(0.831)\end{array}$ & $\begin{array}{l}4.046^{* *} \\
(1.601)\end{array}$ & $\begin{array}{l}-1.395^{* * * *} \\
(0.446)\end{array}$ & $\begin{array}{l}-0.003 \\
(0.004)\end{array}$ \\
\hline $\begin{array}{l}\text { High } \\
\text { remittances } \\
\text { countries } \\
(\mathrm{N}=57)\end{array}$ & $\begin{array}{l}13.370 \text { *** } \\
(3.334)\end{array}$ & $\begin{array}{l}-0.121 * * * \\
(0.017)\end{array}$ & $\begin{array}{c}0.123 \\
(0.440)\end{array}$ & $\begin{array}{l}2.937 * * * \\
(1.038)\end{array}$ & $\begin{array}{l}-0.040 \\
(0.179)\end{array}$ & $\begin{array}{c}0.002 \\
(0.002))\end{array}$ \\
\hline $\begin{array}{l}\text { Low } \\
\text { remittances } \\
\text { countries } \\
(\mathrm{N}=23)\end{array}$ & $\begin{array}{l}11.011^{* * *} \\
(4.681)\end{array}$ & $\begin{array}{l}-0.259 * * * \\
(0.034)\end{array}$ & $\begin{array}{l}-0.001 \\
(0.621)\end{array}$ & $\begin{array}{c}2.779 * \\
(1.425)\end{array}$ & $\begin{array}{l}-0.274 \\
(0.266)\end{array}$ & $\begin{array}{c}-0.0049 * \\
(0.0026)\end{array}$ \\
\hline
\end{tabular}

See Table 1.

The thresholds employed above are arbitrarily set at the mean value of the real interest rate or remittances to GDP ratio. Applying the Hansen (1999) technique to our dataset, the Fstatistics reported in Table 3 confirm the presence of an endogenously-determined thresholds where the threshold variables are defined as the real lending rate and then remittances to GDP ratio. Table 4 reports that as before, there is evidence that the sensitivity of remittances to the real lending rate increases with the real interest rate itself. With reference to Equation (4), an increase in $r$ might be associated with a stronger real exchange rate or fall in $\lambda$ thereby facilitating an increased sensitivity between $R$ and $r$. Given the estimated threshold value for $r$, if $r<-6.637 \%(r>-6.637 \%)$, then the coefficient on $r=0.010(r=-0.024)$. Both the coefficients on $r$ are significantly different from zero. There are a small number of instances where the real lending rate has fallen below (or become more negative than) $-6.637 \%$ for some countries during times of low nominal interest rates and high inflation. These occasions of such low and negative real interest rates are associated with a positive relationship between $r$ and $R$. This suggests that the income effects from changes in real lending rates dominate the substitution effects. 
Table 3. Tests for Threshold Effects

\begin{tabular}{lcc}
\hline Threshold Variable $(q)$ & Real Lending Rate & Remittances to GDP Ratio \\
\hline F-statistic & 38.26 & 233.85 \\
P-value & 0.0090 & 0.0000 \\
$10 \%$ critical value & 19.2246 & 37.8458 \\
$5 \%$ critical value & 24.8798 & 49.7412 \\
$1 \%$ critical value & 37.7538 & 82.6545 \\
\hline
\end{tabular}

These are bootstrapped tests based on Hansen (1999).

Table 4. Estimates of the Threshold Model

\begin{tabular}{|c|c|c|}
\hline Threshold variable $(q)$ & Real Lending Rate & Remittances to GDP Ratio \\
\hline \multirow[t]{2}{*}{$\tau_{0}^{i}$} & -62.758 & -61.939 \\
\hline & $(0.000)$ & $(0.000)$ \\
\hline \multirow{2}{*}{$Y_{\text {mit }}$} & 2.002 & 1.902 \\
\hline & $(0.000)$ & $(0.000)$ \\
\hline \multirow[t]{2}{*}{$Y_{\text {fitit }}$} & 0.797 & 0.889 \\
\hline & $(0.000)$ & $(0.000)$ \\
\hline \multirow[t]{2}{*}{$\lambda_{i, t}$} & -0.766 & -0.835 \\
\hline & $(0.000)$ & $(0.000)$ \\
\hline \multirow[t]{2}{*}{$r_{\mathrm{i}, t} I\left(q_{\mathrm{i}, t-1} \leq \gamma\right)$} & 0.010 & -0.052 \\
\hline & $(0.025)$ & $(0.000)$ \\
\hline \multirow[t]{2}{*}{$r_{\mathrm{i}, t} I\left(q_{\mathrm{i}, t-1}>\gamma\right)$} & -0.024 & -0.001 \\
\hline & $(0.000)$ & $(0.751)$ \\
\hline$\gamma$ & -6.637 & 0.183 \\
\hline R-Squared & 0.531 & 0.587 \\
\hline
\end{tabular}

These are threshold model estimates based on Hansen (1999).

We also find that remittances become less sensitive to the real lending rate as the remittances to GDP ratio increases. This is opposite to our earlier finding where the threshold was arbitrarily set equal to the mean ratio. We now find that if the remittances to GDP ratio is below $0.183 \%$, then the coefficient on the lending rate is negative at -0.053 and significant, but insignificant when the ratio exceeds this threshold.

The estimation in our paper applying the ARDL procedure is intended to shed insight on how the hypothesised relationship of our model holds in the long-run in face of short-run disturbances. In the long-run, remittances, home and host income, lending rates and exchange rate constitute a long-run relationship. This means, for instance, debt-migration, migrant's and family's income, real exchange rate and remittances all grow in a manner that are sustainable to hold an equilibrium among them. If there is a disturbance to this equilibrium in the short-run, such that too much debt or sudden increase in lending rate or a shock in the home income, there will be an adjustment procedure which will bring the relationship 
towards equilibrium. Therefore, it is expected that there will be heterogeneity with regard to the estimated half-lives because different policy variables will have variable impacts on how the economies converge to the long-run relation from a short-run shock. For example, a lowremittance country would imply relatively less dependence on debt-migration, hence faster time to revert to long run path. On the other hand, low interest economies may imply availability of cheap credit and higher incidence of debt-migration and that may result in longer time taken to return to equilibrium relationship.

\section{CONCLUSIONS}

We provide evidence that the long-run effect of a change in the real lending rate on workers remittances is negative. Rather than viewing migrant remittances as the repayment of loans used cover the cost of migration and migrant's education, our evidence is consistent with an altruistic transfer and debt-repayment motive for the basis of worker remittances. Further to this, we find evidence that the relationship between lending rates and remittances is dependent upon the level of real interest rates and whether or not the recipient country is a high remittance country. While a climate of low real interest rates might stimulate an increase in remittances, this will most likely be accompanied by less sensitivity of remittances to real interest rates. If lending rates are increasing through tightening monetary conditions say, then remittances will fall. However, remittances will also become more sensitive to lending rates. There is an important policy implication here insofar as a climate of increasingly tighter monetary conditions may have an increasingly negative effect on remittances. Given the positive viewpoint that is held regarding the role of remittances, policymakers should perhaps take added care in influencing interest rates. 


\section{List of Countries}

Albania

Algeria

Argentina

Armenia

Australia

Bangladesh

Belarus

Belgium

Belize

Bolivia

Botswana

Brazil

Cabo Verde

Cameroon

China

Colombia

Comoros

Costa Rica

Croatia

Cyprus

Dominica

Dominican Republic

Ecuador

Egypt, Arab Rep.

Estonia

Ethiopia

Fiji

Gabon

Gambia, The

Grenada

Guatemala

Guyana

Honduras

Hungary

Iceland

India

Indonesia

Jamaica

Jordan

Kenya
Kyrgyz Republic

Lesotho

Lithuania

Madagascar

Malawi

Maldives

Malta

Mauritius

Mexico

Moldova

Mozambique

Namibia

Nepal

Nicaragua

Nigeria

Norway

Panama

Papua New Guinea

Paraguay

Peru

Philippines

Poland

Romania

Rwanda

Sierra Leone

Slovak Republic

Slovenia

South Africa

Sri Lanka

St. Kitts and Nevis

St. Lucia

St. Vincent and the Grenadines

Swaziland

Syrian Arab Republic

Tanzania

Thailand

Trinidad and Tobago

United Kingdom

Vanuatu

Venezuela, RB 


\section{References}

Acosta, P., Lartey, E. and Mandelman, F. (2007). Remittances and the Dutch disease. in Federal Reserve Bank of Atlanta, Atlanta.

Alleyne, D., et al. (2008). Short-run macroeconomic determinants of remittances to Jamaica: a time varying parameter approach, Applied Economic Letters, 15(8): 629-634.

Amuedo-Dorantes, C. and Pozo, S. (2004). Workers' remittances and the real exchange rate: A paradox of gifts. World Development, 32, 1407-1417.

Adams, R., and Page, J. (2005). Do international migration and remittances reduce poverty in developing countries? World Development, 33, 1645-1669.

Adams, R. J. (2005). Remittances, household expenditure and investment in Guatemala. Policy Research Working Paper Series 3532. Washington, DC: The World Bank.

Arun, T., and Ulku, H. (2011). Determinants of remittances: The case of the South Asian community in Manchester. Journal of Development Studies, 47, 894-912.

Aydas, O. T., et al. (2005). Determinants of workers' remittances: the case of turkey, Emerging Markets Finance and Trade, 41(3): 53-69.

Baltagi, B., Griffin, J. and Xiong, W. (2000). To pool or not to pool: homogeneous versus heterogeneous estimators applied to cigarette demand. Review of Economics and Statistics, 82: 117-126.

Borja, K. (2014). Social capital, remittances and growth. European Journal of Development Research, 26(5), 574-596.

Buckley, M. (2011). From Kerala to Dubai and bank again: construction migrants and the global economic crisis, Geoforum, doi:10.1016/j.geoforum.2011.09.001

Catrinescu, N., Leon-Ledesma, M., Piracha, M., and Quillin., B. (2009). Remittances, Institutions, and Economic Growth. World Development, 37(1), 81-92.

Chami, R., Hakura, D., and Montiel, P. (2009). Remittances: an automatic output stabilizer? IMF Working Paper WP/09/91. Washington, DC: International Monetary Fund.

Chami, R., Barajas, A., Cosimano, T., Fullenkamp, C., Gapen, M., and Montiel, P. (2008). Macroeconomic consequences of remittances Occasional Paper No. 259. Washington, DC: International Monetary Fund.

Chami, R., Fullenkamp, C., and Jahjah, S. (2003). Are immigrant remittance flows a source of capital for development? IMF Working Paper WP/03/189. Washington, DC: International Monetary Fund.

Chami, R., Fullenkamp, C., and Jahjah, S. (2005). Are immigrant remittance flows a source of capital for development. IMF Staff Papers, 52, 55-81.

Chiodi, V., Jaimovich, E., and Montes-Rojas, G. (2012). Migration, remittances and capital accumulation: Evidence from rural Mexico. Journal of Development Studies 48, 1139-1155.

Combes, J., and Ebeke, C. (2011). Remittances and household consumption instability in developing countries. World Development, 39, 1076-1089.

Cooray A. and Mallick D. (2013). International business cycles and remittance flows. The B.E. Journal of Macroeconomics 13(1), 1-33.

Cox Edwards, A., and Ureta, M. (2003). International migration, remittances and schooling: Evidence from El Salvador. Journal of Development Economics, 72, 429-461.

El-Sakka, M. I. T., and R. McNabb. (1999). The macroeconomic determinants of emigrant remittances, World Development, 27(8): 1493-1502. 
Feeny, S., Iamsiraroj, S., and McGillivray, M. (2014). Remittances and economic growth: larger impacts in smaller countries? Journal of Development Studies, 50(8), 1055-1066.

Faini, R. (1994). Workers remittances and the real exchange rate: a quantitative framework, Journal of Population Economics, 7(2), pp. 235-245.

Frank, R., and Hummer, R. (2002). The other side of the paradox: The risk of low birth weight among infants of migrant and nonmigrant households within Mexico. International Migration Review, 36, 746-765.

Giuliano, P., and Ruiz-Arranz, M. (2009). Remittances, financial development, and growth. Journal of Development Economics, 90(1), 144-152.

Gupta, S., Pattillo, C., and Wagh, S. (2009). Effect of remittances on poverty and financial development in Sub-Saharan Africa. World Development, 37(1), 104-115.

Hansen, B. (1999). Threshold effects in non-dynamic panels: Estimation, testing, and inference. Journal of Econometrics, 93(2), 345-368.

Hanson, G., and Woodruff, C. (2003). Emigration and Education Attainment in Mexico. mimeo. University of California, San Diego. Retrieved from: http://irps.ucsd.edu/assets/022/8772.pdf

Hassan, G. and Holmes, M. (2013). Remittances and the real effective exchange rate. Applied Economics, 45, 4959-4970.

Hildebrant, N., and McKenzie, D. (2005). The effect of migration on child health in Mexico World Bank Policy Research Working Paper 3573 and Department of Economics, Stanford University. Washington, DC: The World Bank.

Ilahi, N. and Jafarey, S. (1999): Guestworker migration, remittances and the extended family: evidence from Pakistan, Journal of Development Economics, 58: 485-512.

International Monetary Fund (IMF). (2009). International Transactions in Remittances: Guide for Compilers and Users. Washington D.C.

International Monetary Fund (IMF). (2005). Two current issues facing developing countries. In World Economic Outlook, April 2005: Globalization and External Imbalances. Washington DC: World Economic and Financial Surveys.

Jackman, M. (2013). Macroeconomic determinants of remittance volatility: an empirical test, International Migration, 51, pp. e36-e52.

Kurosaki, T. (2006). Consumption vulnerability to risk in rural Pakistan. Journal of Development Studies, 42(1), 70-89.

Loschmann, C. and M. Seigel. (2014) Revisiting the motivations behind remittance behaviour: Evidence of debt-financed migration from Afghanistan, Migration Letters, 12 (1), pp. 38-49

Luna-Martínez, J. de. (2005). Workers' remittances to developing countries: a survey with central banks on selected public policy issues, Policy Research Working Paper 3638, The World Bank, Washington: DC, http://dx.doi.org/10.1596/1813-9450-3638

Mishra, P. (2005). Macroeconomic impact of remittances in the Caribbean. Unpublished paper. Washington, DC: International Monetary Fund.

Montiel, P. (1999). Determinants of the long-run equilibrium exchange rate: An analytical model. In L. Hinkle and P. Montiel (Eds.), Exchange Rate Misalignment: Concepts and Measurement for Developing Countries. Oxford: Oxford University Press.

Nair, P.R.G. (1991). Asian migration to the Arab world: Kerala (India), in G. Gunatilleke, (Ed.) Migration to the Arab World: Experience of Returning Migrants, United Nations Press, Tokyo: 19-55.

Osella, F. and C. Osella (2000). Migration, money and masculinity in kerala, The Journal of the Royal Anthropological Institute, 6(1): 117-133. 
Page, J., and Plaza, S. (2006). Migration remittances and development: A review of global evidence. Journal of African Economies, 15, 245-336.

Pesaran, M. H., and Shin, Y. (1999) An autoregressive distributed lag modelling approach to cointegration analysis, in S. Strom, (ed.), Econometrics and Economic Theory in the 20th Century: The Ragnar Frisch Centennial Symposium, Cambridge University Press, Cambridge

Pesaran, M. H., Shin, Y. and Smith, R. J. (2001) Bounds testing approaches to the analysis of level relationships. Journal of Applied Econometrics, 16, 289-326.

Poirine, B. (1997). A theory of remittances as an informal family loan agreement, World Development, 25, 221-241.

Quartey, P., and Blankson, T. (2004). Do migrant remittances minimize the impact of macro-volatility on the poor in Ghana? Report prepared for the Global Development Network (GDN). Washington. DC: International Monetary Fund.

Rahman, M.M. (2000). Emigration and development: The case of a Bangladeshi village, International Migration, 38(4).

Rahman, M.M. (2015). Migrant indebtedness: Bangladeshis in the GCC countries, International Migration, 53(6), 205-219.

Rao, B. and Hassan, G. (2011), A Panel Data Analysis of the Growth Effects of Remittances, Economic Modelling, 28(1-2), 701-709.

Ratha, D. (2003). Workers' remittances: an important and stable source of external development finance, in Global Development Finance: Striving for Stability in Development Finance, World Bank, Washington DC: $157-175$

Sayan, S. (2006). Business cycles and workers' remittances: How do migrant workers respond to cyclical movements of GDP at home? IMF Working Paper No. WP/06/52. Washington, DC: International Monetary Fund.

Siddique, A., Selvanathan, E., and Selvanathan, S. (2013). Remittances and economic growth: empirical evidence from Bangladesh, India and Sri Lanka. The Journal of Development Studies, 48(8), 1045-1062.

Singer, A. (2010). Migrant remittances and exchange rate regimes in the developing world. American Political Science Review, 104(2), 307-323.

Stoll, D. (2010). From wage migration to debt migration: easy credit, failure en ei norte, and foreclosure in a bubble economy of the western Guatemalan highlands, Latin American Perspective, 170, 37(1): 123-142.

World Bank (2001). Global economic prospects and the developing countries 2002. Washington, D.C., The World Bank,

World Bank. (2006). The development impact of workers' remittances in Latin America. Vol. 2: Detailed Findings (Chapter 3, Section V). Report No. 37026. Washington, DC: The World Bank.

World Bank (2011), Migration and Remittances Factbook 2011 (2nd ed.), Washington : DC, The World Bank

World Development Indicators (2016) World Development Indicators, Washington DC: The World Bank, http://databank.worldbank.org/data/reports.aspx?source=world-development-indicators

Yang, D., and Choi, H. (2007). Are remittances insurance? Evidence from rainfall shocks in the Philippines. World Bank Economic Review 21, 219-248. 